\title{
Oral Contraceptives, Hormone Replacement Therapy and Thrombosis
}

\author{
F. R. Rosendaal, F. M. Helmerhorst, J. P. Vandenbroucke \\ Departments of Hematology, Clinical Epidemiology and Obstetrics, Gynecology and Reproductive Medicine \\ Leiden University Medical Center, The Netheriand
}

\section{Key words}

Venous thrombosis, myocardial infarction. stroke, oestrogens. progestogens, oral contraceptives, hormone replacement therapy

\section{Summary}

Oral contraceptives and hormone replacement therapy are used by hundreds of millions of women worldwide. Since the early 1960s it is known that female hormones increase the risk of venous thrombosis, myocardial infarction and stroke. This risk is still present with current low-dose oral contraceptives and, even though in absolute terms the risk is small, oral contraceptives form the major cause of thrombotic disease in young women. The risk is higher during the first year of use (up to 1 per 1000 per year), with the use of desogestrel- or gestodenecontaining oral contraceptives ("third generation progestogens") and among women with a prothrombotic predispositon. Hormone replacement therapy increases the risk of venous thrombosis, while results of randomised trials so far do not substantiate the expectation of a beneficial effect on the risk of arterial cardiovascular disease. First results are emerging that specific subgroups of women, with prothrombotic or other abnormalities, may be at risk, especially during the first years of use of hormone substitution.

\section{Introduction}

Symptomatology and Epidemiology

Venous thrombosis has an annual incidence of $1-3$ per 1000 indıviduals per year $(1,2)$. It is uncommon in young individuals and becomes more frequent with advancing age (1). It mostly manifests in the deep veins of the leg, but may occur in other sites, such as the upper extremities, cerebral sinus, liver and portal veins or retinal veins. Embolisation occurs when parts of the clot dislodge and are transported by the blood flow, usually through the heart to the vasculature of the lungs ( 3 ).

Thrombosis is a serious disorder; it can result in fatal pulmonary embolism. Estimates of the case fatality rate of venous thrombosis vary widely. Two large natural history studies $(2,4)$ found that $12-25$ percent of all events of venous thrombosis were fatal. while recent trials found much lower figures, around 1-3 percent (5-10 percent for pulmonary embolism) (5-7). This wide range may be caused by the inclusion of thrombosis as secondary cause of death in the studies with a high estimate, and the selection of patients with a good prognosis in clinical trials. The Worcester study also showed that the case fatality rate was

Correspondence to: Prof. Dr F. R. Rosendaal. Clincal Epidemiology, Bldg 1. C0-46. LUMC, P. O. Box 9600. NL-2300 RC Leiden. The Netherlands Tel.: +31-71-5264037: Fax:+31-71-52+8122: E-mal fr.rosendaal@lumc.n! highly dependent on age. with a low mortality among those aged fon or less at the time of thrombosis (2). The posthrombotic syndrom leads to chronic morbidity in a substantial number of patients (8).

Risk factors for thrombosis are usually divided into genetic an acquired factors. Mechanistically, they fall into three groups of cauts according to Virchow: reduced blood flow, changes in the vessel u2: and changes in the composition of the blood (9). For venous thronth sis, the first (stasis) and third group (changes in blood coagulabilit appear most prominent, while for arterial disease, factors that affe: the vessel wall, i.e. promote atherosclerosis, are most relevant. $\pi$. genetic risk factors for venous thrombosis are all associated with cha: ges in the blood composition, while acquired causes are either aw ated with decreased flow, i.e., immobilisation, paralysis, surger. plaster casts, or related to blood coagulation, such as the lupus an: coagulant, pregnancy, oral contraception, malignancies. Table 1 ls: the main risk factors for venous thrombosis.

\section{Hormones and Venous Thrombosis}

The first report of venous thrombosis related to the use of oral io traceptives was in 1961, when Jordan wrote about a nurse who hi: developed pulmonary embolism. shortly after starting a course 0 : 1 combined oral contraceptive containing $100 \mu \mathrm{g}$ mestranol for the trec ment of endometriosis (10). It has subsequently been shown that $x^{*}$ trogens increase the risk of thrombosis in women, when used as res contraceptive or as hormone replacement therapy in postmenopas women (11-13). Oestrogens also increase the risk of thrombosis in mt: which became apparent when they were tried in the treatment of $a$. nary disease (14) as well as in the course of sex change treatment is More recently, it has been demonstrated that not only oestrogen to also progestogens in combination oral contraceptives may increax risk of thrombosis (16-18), while progestin-only preparations mal is increase the risk of thrombosis $(19,20)$.

\section{Oral Contraceptives}

Composition

Most oral contraceptive drug preparations supply an oestrogen ats progestogen. In the majority of oral contraceptives used, these art he contained in each pill (monophasic preparations), and a woman the same combination for three weeks, followed by a pill-free durng which a withdrawal bleeding takes place. The mode of uth * the suppression of the ovulation process through the combined at of the progestogen and to a lesser extent the oestrogen compount progestogen compound suppresses luteinizing hormone ( $\mathrm{LH}$ a a d LH-surge, while the oestrogens suppress follicle stimulating horat (FSH). Since the amount of oestrogen has been minimised, oret follicle development can be detected during pill use. The major 


\begin{tabular}{lll}
\hline acquired & inherited & mixed/unknown \\
\hline $\begin{array}{l}\text { age } \\
\text { previous thrombosis }\end{array}$ & $\begin{array}{l}\text { antithrombin deficiency } \\
\text { protein C deficiency }\end{array}$ & $\begin{array}{l}\text { hyperhomocysteinaemia } \\
\text { high levels of factor VIII }\end{array}$ \\
$\begin{array}{l}\text { protein S deficiency } \\
\text { fajor surgery }\end{array}$ & $\begin{array}{l}\text { APC-resistance in the } \\
\text { orthopaedic surgery }\end{array}$ & $\begin{array}{c}\text { absence of FVL } \\
\text { malignancy }\end{array}$ \\
$\begin{array}{l}\text { pral contraceptives } \\
\text { hormonal replacement therapy } \\
\text { antiphospholipid syndrome }\end{array}$ & dysfibrnogenaemia & high levels of factor XI \\
myeloproliferative disorders & & high levels of TAFI \\
polycythaemia vera & & \\
\hline
\end{tabular}

fockesugen component in the pill is to prevent spotting and breaksnugh bleedings by organizing the endometrum. In biphasic and raphusi combinations. the content of the pills taken during one cycle $+2 \pi \mathrm{r}$. wth more oestrogens in the early phase of the cycle, and more froverogem in the later phase of the cycle. Some preparations only sutusn a progestogen, and are mainly used when oestrogens are conskred contra-indicated; they cause a higher frequency of spotting and Weukthrough bleedings leading to a lower compliance. Most oral contracepres have a $1 \%$ failure rate with complete compliance. Since progrtogens also affect the viscosity of cervical mucus, even ovulations that do occur (escape ovulation) during perfect use seldomly lead to pegnancy. Reliability of progestogen-only oral contraceptives is probwh sumlar to those for combined oral contraceptives (21).

Naturally ociurring sex steroids are inactive when taken orally. Hence, early research in the 1930 s focussed on manufacturing slightly wtered hormones that could be taken orally. Adding an ethinyl group at 17-pustion of oestradiol led to the potent oral oestrogen ethinylestradiol, which was subsequently used in oral contraceptives. Mestranol is the 3-methylether of ethinyloestradiol, which is rapidly tretabolsed into ethinyloestradiol, and has also been used in oral consaceptures.

Orally active progestogens are predominantly based on the synthetic toveron dersvative ethisterone. The progestogens in this class, which ate all those currently used in oral contraceptives, are called 19-norieverones There is no formal classification system of progestogens and they are usually grouped into "generations" based on when they were irst produced. First generation progestogens include norethisterone, wrethynodrel, lynestrenol and ethynodiolacetate. The second generation includes norgestrel, levonorgestrel and norgestrione. The third generaunn includes desogestrel, gestodene and norgestimate. Although, temporally. norgestimate should be included in the third generation group, it is also often classified among second-generation progestogens, since fter uptake it is partly converted to levonorgestrel.

The first human trial with oral contraceptives was performed in 1956, and the first licensed use for birth control was in 1959, the culmunation of nearly 40 years of research that began with animal experiments of ovarian transplantation in 1921 in Innsbruck (22). Since the first use. changes in the composition of oral contraceptives have concemed the oestrogen dose and the progestogen compound. Enovid, the first oral contraceptive in the USA, contained $150 \mu \mathrm{g}$ mestranol. Over the years, the oestrogen dose has been reduced from $100-150 \mu \mathrm{g}$ first to $\$ 0 \mu \mathrm{g}$. then to $30-35 \mu \mathrm{g}$, while some oral contraceptives that are cur- rently available contain only $20 \mu \mathrm{g}$ ethinyloestradiol. For the progestogen compound in combined oral contraceptives, change over time concerned the chemical composition of the progestogen rather than the dose. While the first oral contraceptives contained a first generation progestogen, the second generation was used throughout the seventies, and the third generation progestogens became widely used from the mid-1980s onward (new oral contraceptives were introduced in different countries at various times, e.g., oral contraceptives with a third generation progestogen had a majority market share in Southern Europe in the beginning of the 1990s, when they were only just entering the market in the USA).

Currently, over a 100 million women worldwide use oral contraceptives (23). This widespread use by young and usually healthy women indicates that even a rare deleterious effect could affect many women, at an age when serious disease is infrequent. Serious cardiovascular side effects of oral contraceptives are thrombotic events, including venous thrombosis, myocardial infarction and stroke. In this review we will mainly focus on venous thrombosis.

\section{Older Studies on Risk of Venous Thrombosis and OCs}

After the first report in 1961, more case reports followed rapidly. A hallmark study, comparing women with thombosis to control women without thrombosis (case-control study) was based on data recorded by the Royal College of General Practioners (24). In this study, published in 1967, it was found that oral contraceptives increased the risk of thrombosis nearly 3 -fold. Another British study found a relative risk of $6(25,26)$, and two US studies yielded relative risks of 4 and 11 $(27,28)$. In the 1970 s, large prospective follow-up studies were conducted which confirmed the results of the case-control studies (29-31). The risk estimates from studies published before 1990 are shown in Fig. 1. Overall, the studies pointed to a 3 -fold increased risk of venous thrombosis in users of oral contraceptives (32). Several important attributes of the risk emerged from these studies: the risk does not increase with longer duration of use, and disappears immediately when oral contraceptives are discontinued, i.e., past-users do not have an increased risk. Higher relative risks were found for idiopathic than for secondary thrombosis (25-27, 33).

Most of these studies were performed before objective testing for venous thrombosis was possible or in widespread use. We know that a substantial proportion of all clinical diagnoses of deep-vein thrombosis are false-positives $(34,35)$, 0 it is likely that these early studies suffer- 


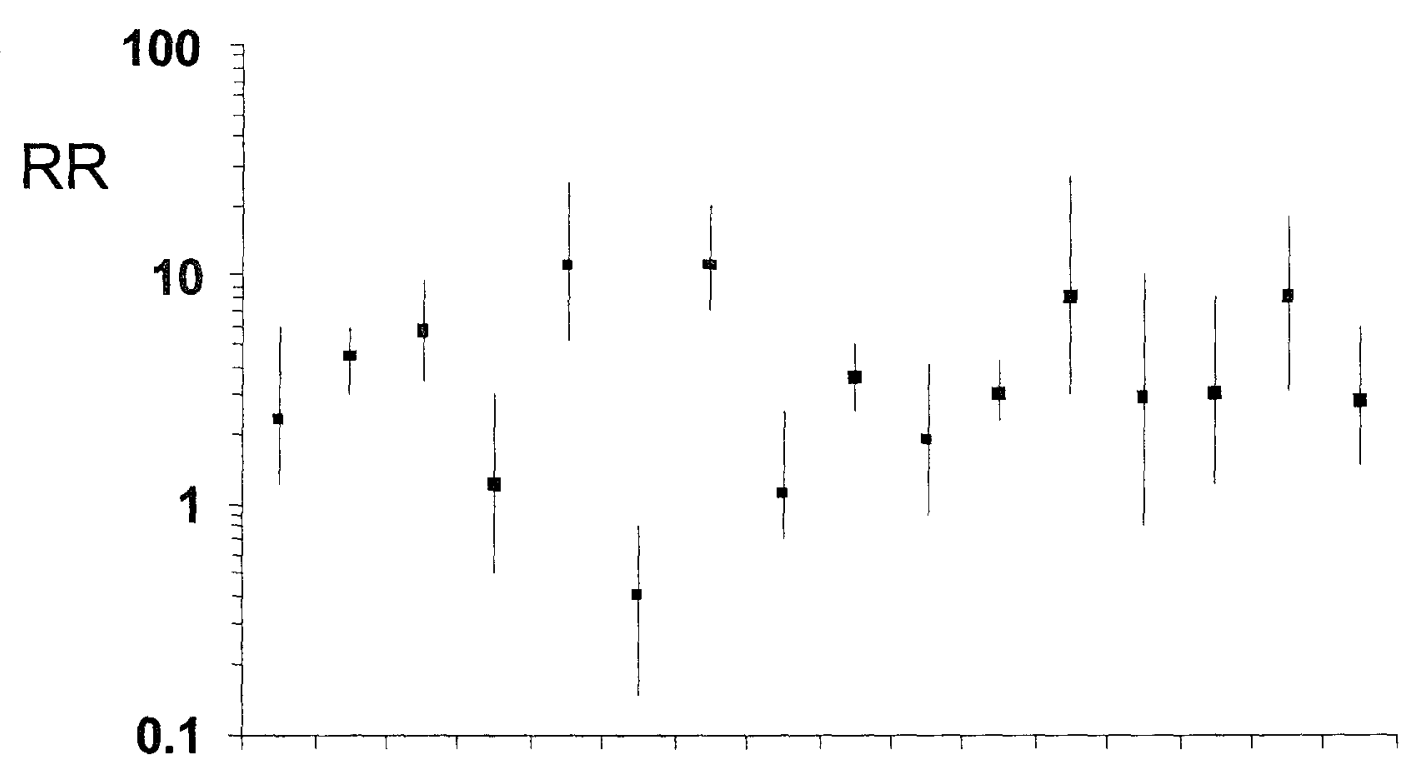

$\begin{array}{llllllllllllllll}67 & 69 & 69 & 71 & 73 & 74 & 75 & 78 & 78 & 78 & 79 & 82 & 85 & 86 & 87 & 89\end{array}$

Fig. 1 The relative risk for icnous thrombosis in oral contraceptive use. The relativc risks (users vs. nonusers) are shown from studres published between 1967 and 1989. with 95\%-confidence intervals. A relative risk of 1 indicates equal risks, a relative risk exceeding one indicates a higher risk for users than for nonusers. The studies include case-control studies (24. 26-28, 46, 160-163), follow-up studies (29-31, 165167) and one randomized controlled trial (168). Some figures were estimated from data in the original papers

ed from substantial misclassification with regard to venous thrombosis. Studies that divided diagnoses by level of certainty (e. g. "definite" vs. "probable" vs. "possible") thrombosis, or those that focussed on the more severe events, usually reported higher relative risk (25-27, 30, 31,36 ), which supports the existence of misclassification. This suggests that the risk of oral contraceptives is underestimated in the older studies.

\section{Recent Studies on Risk of Venous Thrombosis and OCs}

Studies in the 1990s showed similar relative risk estimates to the earlier studies with a two- to six-fold increased risk of venous thrombosis (37-40), while several studies published after 1995 showed a risk differential by progestogen content (see below). The absolute risk of venous thrombosis in women of reproductive age is estimated at $1-2$ per 10,000 per year $(1,2,41)$. Data of Dutch national registries showed incidence rates of all venous thrombotic events among young individuals of 2 per 10,000 per year in those aged 15-24 years, and 4 per 10,000 per year in those aged 25-39 (42). In another Dutch study, an annual incidence for deep-vein thrombosis was reported of 0.8 per 10,000 among women not using oral contraceptives, and 3.0 per 10,000 per year in oral contraceptive users (37). A similar rate of 2.0 per 10,000 among users of oral contraceptives was reported for women in the United Kingdom (43). In absolute terms, these risks do not seem large. On the other hand, since oral contraceptives are used by large numbers of women, their use is responsible for the majority of all venous thrombotic events in young women (44).

\section{Referral Bias}

Some have sought to explain the absence of a reduction of the risk of thrombosis associated with the use of oral contraceptives since the 1960s by so-called referral or diagnostic suspicion bias. The idea is that physicians would, when consulted by a woman with complaints that could point to thrombosis, preferentially refer those who used oral contraceptives for further diagnostic tests. This would lead to an overestimate of the frequency of oral contraceptive use among thrombosis patients, and subsequently an overestimate of the risk when these pa- tients were compared to a randomly selected control group of women without thrombosis. Two studies have demonstrated that this bias does not explain the currently observed risk estimates $(45,46)$. In these studies, women referred for diagnostic tests for thrombosis and who subsequently tested positive, were compared to women referred for the same reason but who tested negative. Because patients and controls were referred under the same suspicion of thrombosis, referral and diagnostic suspicion bias were eliminated. Relative risks associated with oral contraceptive use were $6.4(45)$ and $3.9(46)$, i. e., very similar to recent studies with population controls.

\section{Effect of Oestrogen Dose}

Since the early use of oral contraceptives the oestrogen dose has gradually been decreased, from 100-150 $\mu$ g ethinyloestradiol or mestranol in the first brands, to 50 and $30 \mu \mathrm{g}$, and recently even to $20 \mu \mathrm{g}$ ethinyloestradiol. The expected result of this change was a reduction in the incidence of cardiovascular side effects. Such a trend is not obvious when the risk estimates found in studies published from the 1960 s to the 1990s are evaluated, as Fig. 1 shows: the risks do not appear to have decreased over time. However, such a time-trend, or the absence of it. may be deceiving because of other changes that occurred over time. such as improvements in diagnostic methods. In several studies, a lower risk for oral contraceptives with a lower oestrogen content was found $(31,36,47)$. In the most recent of these, the risk of venous thromboss was increased over 10-fold (compared to non-users) for oral contraceptives containing more than $50 \mu \mathrm{g}$ ethinyloestradiol, and 4-fold for those containing less than $50 \mu \mathrm{g}$ ethinyloestradiol (47). Reports from several other studies, however, did not identify a difference between oral contraceptives by oestrogen dose $(16,30,39,48)$. In the Leiden Thrombophilia Study, a direct comparison of oral contraceptives containing either $30 \mu \mathrm{g}$ or $50 \mu \mathrm{g}$ ethinyloestradiol, and the same second generation progestogen (levonorgestrel), showed 3- to 4-fold increased risks for both oestrogen dosages compared to non-users (16).

It seems plausible from the available literature that the earliest cont traceptives containing $100 \mu \mathrm{g}$ or more ethinyloestradiol conferred higher risk of venous thrombosis than current formulations containing $50 \mu \mathrm{g}$ or less. It remains highly questionable whether the further reduc. 


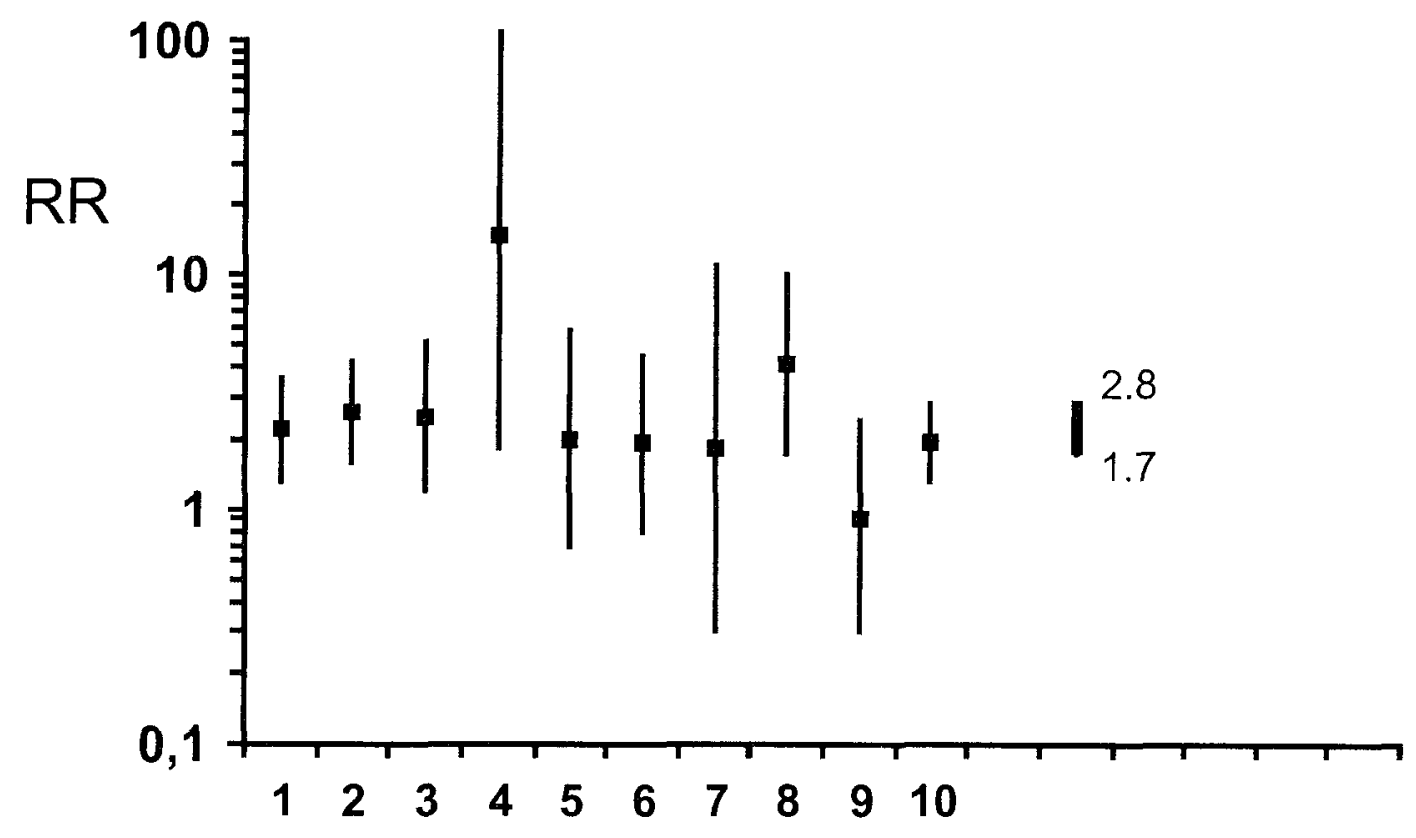

*n in $\mu \mathrm{g}$ ethnyloestradiol led to a further lowering of risk, while 'frre ure no data at all suggesting a lower risk of the newest oral conrusperses contanning only $20 \mu \mathrm{g}$ ethinyloestradiol.

\section{: How of Progestogen Content}

tit the end of 1995, three studies simultaneously reported an increasand of venous thrombosis in women who used oral contraceptives wh the progestogens desogestrel or gestodene ("third generation coniraepue.") (16-18). Subsequently, more than 10 studies have rerned on this issue, most of which confirmed that oral contraceptives vntanning desogestrel or gestodene had an increased risk of thrommo 143. 46. 49-53), while some did not (54-57). Fig. 2 shows the vumuter of non-commercially-sponsored studies (to reduce heterogexit! of ewmates $[58,59]$ ), with a summary $95 \%$-confidence interval $\because \mathrm{A} \mid \mathrm{T}$ - to 2.8-fold increased risk of third-generation versus secondsitnerstion oral contraceptives. The risks are considerably higher during the firv year of use (60) and then might become as high as 3 per 1000 per year tor users of oral contraceptives containing a third generation progevtogen (53).

There findings have led to considerable controversy and several inherent blases were claimed to be present (61-66). These were said to inilude preferential prescription, diagnostic bias, attrition of suscepubler. starter or healthy-user effects, effects of switching types of oral contraceptives, and effects of different age distributions of the users of arous oral contraceptive types. From reanalyses of previously published data, and new studies, it was claimed that such biases were present $(20.55,56,67-69)$. Thus controversy has fuelled the debates $43.70-73)$. It has been pointed out that commercial interests may have affected the debate $(58,59,74,75)$ and that "considerable sums of mone! have been spent in denigrating well conducted studies with both dear hypotheses at the outset and clear analyses, studies which unexattedly found that newer pills containing desogestrel and gestodene Aere dryociated with higher risks of venous thrombosis than older preparations with other progestogens. Often highly personalised attacks hutc been made to discredit the work of well-respected researchers, resulatory authorities, and the World Health Organisation" (76).
The various possible biases that have been proposed have been carefully reviewed, and it was concluded that they could not explain the observation of a higher thrombotic risk with oral contraceptives containing the third generation progestogens desogestrel and gestodene (77-79). An independent expert committee convened by the World Health Organisation came to the same conclusion (80).

One of the original aims in developing contraceptives with a third generation progestogen was to reduce the risk of myocardial infarction. An early study suggested such a beneficial effect (81), while other studies did not $(82,83)$. Since each of these included fewer than 30 women with a myocardial infarction who used oral contraceptives (and fewer than 10 who used third generation contraceptives), no conclusions could be drawn. A large study in the United Kingdom of more than 400 women with a myocardial infarction at a young age, including 40 patients who used oral contraceptives ( 20 with a third generation brand) yielded no evidence for a reduced risk (relative risk 1.8, 95\% confidence interval $0.7-4.8$ for third versus second generation oral contraceptives) (84). It has been known for many years that oral contraceptives have a variety of metabolic effects, including effects on the procoagulant, anticoagulant and fibrinolytic system $(85,86)$. These changes were within the normal range and therefore considered of little relevance, while it was also suggested that the pro- and antithrombotic effects might keep each other in balance $(85,86)$. In 1997, it was first reported that third generation oral contraceptives had a different and stronger procoagulant effect than second generation contraceptives, in a test that quantified the response of plasma to activated protein $C$ (APC) on thrombin generation (87). In this test, the endogenous thrombin potential (ETP), which is defined as the time-integral of free thrombin concentration, usually derived from residual levels of amilodytic activity ( $\alpha 2 \mathrm{M}-\mathrm{Il}$ ) , is determined in the presence and absence of added activated protein $\mathrm{C}$, yielding an APC-sensitivy ratio (87). The major difference of this EPT-APC-sensitivity ratio to the standard APC-resistance test $(88,89)$ is that initiation of coagulation takes place via the extrunsic pathway by tissue factor, while the original test is based on the APTT (87-89). The ETP-APC-sensitivity test proved effective in detecting factor V Leiden, as was the APTT-based APC-sensitivity test, but showed much greater sensitivity to hormonal effects, which only 
led to mild changes in the APTT-based APC-senstivity test (90.91). With this test. a clear difference $w$ as found between users of second and third generation contraceptuves (87). From the results in individuals with various factor $V$ genotypes (Leiden or wildtype) and non-users and users of various types of oral contraceptives. it was apparent that in the ETP-APC-sensitivity test. third generation oral contraceptives induced a coagulation abnormality of about the same magnitude as that seen in carriers of factor $V$ Leiden. This coincides with the approximately equal clinical effects. ie, a 7 - to 8 -fold increased risk of venous thrombosis for carriers of factor $V$ Leiden. and a 6-to 10-fold increased risk of venous thrombosis in users of third generation oral contraceptives compared to women not using an oral contraceptive $(77,87)$. This study was criticised on design issues which led to a randomised crossover study, in which women volunteers used an oral contraceptive with levonorgestrel (second generation progestogen) for a fixed period of two cycles, and an oral contraceptive with desogestrel (third generation progestogen) for two cycles, in a randomised order with a two-cycle wash-out period in-between (92). In this study contraceptives were compared on a large number of effects on procoagulant, anticoagulant and fibrinolytic factors (92-95). First of all. the pronounced effect of oral contraceptives containing desogestrel in inducing APC-resistance was confirmed (92). Secondly, while levonorgestrel-contaning contraceptive increased factor VII. as had been reported earlier (reviewed in $[85,86,96,97])$. the increase was much larger with desogestrel-containing contraceptive (12\% vs. $32 \%$ increase) (93). Thirdly, desogestrel-containing oral contraceptive led to a decrease in both total and free protein $S$, while no effect of the levonorgestrel-containing oral contraceptive was observed (95). Finally, in an analysis of fibrinolytic parameters, increased endogenous fibrinolytic parameters were observed for both types of oral contraceptives. which was, however, not accompanied by a change in clot lysis time, suggesting that the increased fibrinolytic actıvity during oral contraceptive use was counterbalanced by TAFI-mediated down-regulation of fibrinolysis (94). This down-regulation of fibrinolysis, which is factor XI-independent, was more pronounced with the desogestrel-than with the levonorgestrelcontaining contraceptive (94). The overall picture from these studies is that oral contraceptives with a third generation progestogen affect the haemostatic system in a more pronounced way than contraceptives with a second generation progestogen, in a direction that is prothrombotic. It has been been demonstrated in the Leiden Thrombophilia Study that APC-resistance as established by the enogenous thrombin potential (ETP-APC-sr) is a strong predictor of venous thrombosis, which clinically validates the results of the laboratory studies with this test (98).

\section{Effect of Other Risk Factors}

In women with deficiencies of natural anticoagulant proteins, i.e., protein $C$, protein $S$ or antithrombin, high risks of venous thrombosis have been found among oral contraceptive users. In selected famılies with familial thrombophilia due to these deficiencies, annual risks among oral contraceptive users ranged from 6-27 percent, with the highest risk in antithrombin deficient women (99). In female relatives of unselected patients with these deficiencies, oral contraceptive use also increased the risk of thrombosis. by 6- to 8-fold (100) over above the thrombotic risk brought about by the thrombophilic defect.

Several studies have shown that APC-resistance is common (10-37 percent) among women who developed thrombosis during oral contraceptive use $(50,101,102)$. In two population-based studies a high risk was found for factor $V$ Leiden carriers who used oral contraceptives, indicating 20- to 30 -fold increased risks compared to women without factor $V$ Leiden who did not use oral contraceptives (37.54). In a comparison of unselected relatives with various thrombophilic defects, the synergistic effect with oral contraceptives appeared even higher for deficiencies of natural anticoagulants than for factor V Leiden (100). The interaction of oral contraceptives with factor $V$ Leiden was most striking for those using a third-generation progestagen (16). Homozygosity for factor $V$ Leiden leads to a 50- to 100 -fold increased risk of venous thrombosis (103). In a series of homozygous patients, 80 percent of the women with thrombosis had been using oral contraceptives, which suggests a very high risk of oral contraceptives in these women (104).

The prothrombin $20210 \mathrm{G}$ to $\mathrm{A}$ variant, which by itself increases the risk of thrombosis 2- to 4-fold (105) also interacts synergistically with oral contraceptives, with a 16 -fold increased risk of thrombosis in carriers who used oral contraceptives compared to non-carrier nonusers (54).

High levels of factor VIII are, like factor V Leiden and prothrombin 20210A. common in the general population and may therefore affect many individuals $(106,107)$. The combination of high levels of factor VIII and use of oral contraceptives was associated with a 10 -fold increase in risk compared to individuals with lower levels $(<150 \mathrm{IU} / \mathrm{dl})$ who did not use oral contraceptives. This estimate did not exceed the sum of the separate effects of the two risk factors (108).

The synergistic effects with oral contraceptives on the occurrence of deep vein thrombosis of factor V Leiden and prothrombin 20210A, and deficiencies of protein $C$, protein $S$ and antithrombin, are also present for thrombosis at unusual sites. The risk of cerebral vein thrombosis was highly increased in women with either factor $\mathrm{V}$ Leiden or prothrombin 20210A who used oral contraceptives $(109,110)$.

\section{Screening for other Risk Factors}

When other factors enhance the risk of oral contraceptives, consideration could be given to screening for abnormalities prior to prescription. Theoretically, screening may offer benefit if the joint effect of the two risk factors exceeds the sum of the separate effects, in which case withholding oral contraceptives from the high-risk group would lead to a larger reduction of thromboses than random withholding (111). For deficiencies of protein $\mathrm{C}$, protein $\mathrm{S}$ and antithrombin, it is obvious that the population prevalence is too low to render screening for these abnormalities worthwhle. This may be different for factor $\mathrm{V}$ Leiden and prothrombin 20210A, each of which has a population prevalence of several percent. Some have argued that the risks of thrombosis, even in the presence of such a genetic defect and oral contraceptive use, are still small in absolute terms (less than 3 per 1000 per year), and that therefore the number of women needed to screen to prevent one fatal thromboembolism is very high $(112,113)$. Others have taken a more proactive view towards screening, citing as a reason the severe morbidity that may follow non-fatal thrombotic events, e.g. the posthrombotr syndrome (114). It is important to realise that the issue of screening involves other issues than thrombosis morbidity and mortality, but also psychological effects, social effects (e.g. insurance problems). and. finally, cost. Data balancing all these various aspects are currently lacking, and in the absence of convincing data screening cannot be recommended.

\section{Biological Mechanism}

Over the last few years major advances have been made in under standing why oral contraceptives cause thrombosis. Numerous publica- 


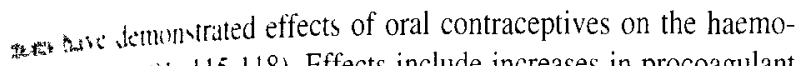
ass. III witor $X$ factor XII and factor XIII, reductions in the anticoand sen phumugen (reviewed in $[85,86,96]$ ). The net effect is an

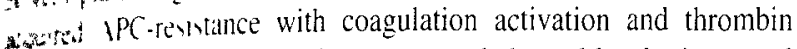
(1) snalut atulty (94). It is not clear how oral contraceptives exert me wnu hochemical effects on the molecular level. i.e., what w w plused by the hormone receptors, or how the oestrogen and

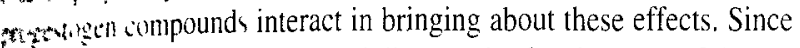
thromboss is a multicausal disease, the development of thromays all aral contraceptive user will be the result of interactions with mer sind listors, such as the genetic make-up of the woman $(16,119)$. is ne ken hown that the haemostatic system of some women, the * w the h her-responders, is more sensitive to exposure to oral conrestis isan that of others, and it is plausible that these women are uthener mh of dereloping thombosis (120).

\section{Din $t^{+}$lan ral Disease}

Orul wntruceptives also increase the risk of myocardial infarction, wot reperted in 1963 (121), of ischaemic stroke, first reported in 1968 . 3 , and of haemorrhagic stroke, first reported in 1973 (122). A recent wity by the World Health Organisation showed a 5-fold increased risk tram moardial infarction (83). This, and other studies reviewed in the :WH WHO Report on cardiovascular disease and oral contraception (v) confirmed a high risk in women with major cardiovascular risk ixtors. in particular smoking and hypertension. The recent study by the Horld Health Organisation on ischaemic stroke showed a 3 -fold inreased n $1 \mathrm{k}$ associated with the use of oral contraceptives (123), and a 15-10 2-fold increased risk of haemorthagic stroke (124).

\section{Hormone Replacement Therapy}

Etyctutum and Early Results

Povmenopausal hormone substitution has been used for several wiade (125. 126). While in the 1970 s only a few percent of postmonupusul women used hormone replacement therapy, it became Wuespread in the 1990s (11-13, 125). The early indication was relief if menopausal symptoms, but more recently it was suggested that hormone replacement therapy could confer other benefits, affecting major twewser. This was based on the observation of the more rapid progreswon of osteoporosis and development of cardiovascular disease in women after menopause. It was hypothesised that hormone replacement therapy would reduce the development of osteoporosis and the acidence of fractures, and lower the incidence of cardiovascular disease. in particular myocardial infarction. Observational studies in the early 1980 confirmed these effects (127-133). For cardiovascular disease, impressive risk reductions were reported, with a halving of the risk of iardiov ascular events and cardiovascular death $(129,130)$, and even a imlar risk reduction for all-cause mortality (131). It was also shown. bowerer. that women who used hormone replacement therapy often nad a different cardiovascular risk profile than non-users. and that vection bias offered an alternative explanation for the apparent benein (134-136). To resolve this matter. several randomised. controlled. thal, have been performed or are in progress.

\section{Composition and Types of HRT}

Early hormone replacement therapy consisted of an oestrogen only (oestrogen replacement therapy, ERT, also referred to as unopposed hormone replacement therapy). Because of the strong evidence that unopposed oestrogen therapy increased the risk of endometrial cancer (reviewed in [126]), nowadays oestrogen-only hormone replacement therapy is restricted to women after hysterectomy, while. for women with an intact uterus, a progestogen compound, e. g. medroxyprogesterone acetate, is added. Conjugated oestrogens used in oral preparations are distilled from urine of pregnant mares. Micronised oestradiol and oestradiol-valerate that is hydrolised to oestradiol is also available in tablets (137). Alternatively, oestradiol may be delivered transdermally (patches). percutaneously by gels, subcutaneously by pellets every six months and rarely. nasally. It is generally thought that the oestrogen dose in hormone replacement therapy is lower than in oral contraceptives. It should be noted. however. that comparing the effective doses of different compounds from very different origins with different clinical assays, is problematic.

\section{Risk of Venous Thrombosis}

In the first systematic study of adverse effects of hormone replacement therapy, in 1974, a slight excess of oestrogen users was reported among patients with venous thrombosis compared to healthy controls (14\% versus $8 \%$ ). Subsequent studies failed to find an association (138-140) and in commentaries it was authoritatively stated that the notion that oestrogen replacement therapy could cause venous thrombosis was based on "medical superstition" (141). In 1996, a number of studies showed that the risk of venous thrombosis was increased in users of hormone replacement therapy (11-13, 142). These four observational studies reported relative risks for current users between 2.1 and 3.6 compared to non-users. These, and subsequent studies that confirmed the association between hormone replacement therapy and venous thrombosis (143-147) included case-control studies and prospective follow-up studies, concerned deep vein thrombosis as well as pulmonary embolism. and dealt with idiopathic and secondary thrombosis. In most studies, the risks were highest in the first year of use $(11,12,143,144.147)$, with a complete restriction to the first year in some studies $(143,144.147)$, while in other studies the risk also remained elevated after several years of use $(11,146)$. Elevated thrombotic risks were found for users of oral as well as users of transdermal hormone substitution $(143,144)$ and for conjugated oestrogens as well as for oestradiol $(143,147)$.

One may wonder why the early studies did not detect a risk, while in recent studies hormone replacement therapy was shown to increase venous thrombotic risk, which even was of the same magnitude as the relative risk brought about by oral contraceptives. One explanation is the lack of objective diagnostic testing for venous thrombosis in the older studies. A misclassification that would result in the inclusion of many individuals in the case-group who are actually not suffering from thrombosis, thereby diluting the effect. It is not implausible that the high oestrogen doses in oral contraceptives led to a high risk of thrombosis which was detectable in studies performed with unreliable diagnostic methodology, which lacked the accuracy to detect the risk brought about by hormone replacement therapy. A second explanation is the low prevalence of use of hormone replacement therapy at the time of the early studies, which led to a low power to detect differences in risk. In the Boston Collaborative Drug Surveillance Program. the 
frequency of hormone substitution was $8 \%$ in the control population and $14 \%$ (age-standardised) among the patients. which would yield a relative risk estimate of nearly two. with wide confidence intervals since the prevalences were based on only 18 women with venous thrombosis (125). Interestingly, the only recent study that did not find an association between hormone replacement therapy and the risk of venous thrombosis. also had a low frequency of use anong the healthy population, of 5 to $6 \%$ (139). In contrast, in most of the other studies well over $25 \%$ of control women used hormone substitution (11-13. 147), up to 50\% in the randomised trial (146).

Of special interest is a randomised trial among women with prior venous thrombosis (137). This study was terminated when other studies pointed to an increased thrombotic risk with hormone replacement therapy $(11-13,145)$ and showed a high rate of recurrence of 8.5 percent per year in the treatment group (versus 1.1 percent per year in the placebo group) (137).

\section{Risk of Arterial Thronbosis}

While observational studies have suggested a clear benefit of hormone replacement therapy for the development of arterial disease, this has not been borne out by a randomised trial, rendering further credibility to the self-selection of women with a better cardiovascular risk profile amongst users of hormone replacement therapy. The Heart and Estrogen/progestin Replacement Study (HERS) was a secondary prevention trial, in which over 2500 women with prior coronary disease were randomised to receive either hormone substitution or placebo (148). Over the five year duration of this trial, in which an excess of venous thrombosis was observed $(145,146)$, no benefit with regard to arterial disease could be demonstrated ( $\mathrm{RR}=1.0, \mathrm{Cl} 950.8-1,2)$. Posthoc analyses suggested a pattern of early harm and late benefit, with rate ratios of 1.5 in the first year, and 0.75 in the fourth and fifth year of use (148). The Women's Health Initiative (149) is a large on-going placebo-controlled primary prevention trial in which nearly 30000 women have been enrolled. In the first two years of this large study, an excess of both myocardial infarction and venous thrombosis was observed in the treatment group (150).

\section{Effect of other Risk Factors}

The high risk of venous thrombosus during early phases of use suggests, as for oral contraceptives (151), that there is a subgroup of women with a genetic predisposition to thrombosis who are at particular risk when exposed to hormone replacement therapy. The results of HERS indicate that this is also likely to be the case for arterial disease (148). In the study of hormone replacement after prior venous thrombosis, the majority of women who experienced a recurrence had genetic (factor V Leiden) or acquired (anti-cardiolipin antibodies) predisposition (137). In a re-analysis of the Oxford case-control study (11), a high risk of thrombosis was observed in women who were resistant to APC (152). In a subsequent genetic analysis, we found that, while the presence of a prothrombotic mutation (either factor $V$ Leiden or prothrombin 20210A) increased the risk of thrombosis 4.5 -fold, and the use of hormone replacement therapy increased the risk 3.6-fold, the combination of these two risk factors led to an 11 -fold increased risk. This suggests a synergistic effect (Rosendaal, unpublished data). Recently, it was reported that in women with a prothrombotic gene defect (prothrombin 20210A), hormone replacement therapy increased the risk of myocardial infarction. The effect of this therapy was most pronounced among hypertensive women (11-fold increase), while women without the prothrombotic variant had no increased risk of myocardial infarction when using hormone substitution (153). A study has been started to investigate women who develop thrombotic events during the first year of the primary prevention trial (WHI) for susceptible subgroups due to genetic abnormalities.

\section{Biologic Effects}

Hormone replacement therapy affects many biological parameters. In a randomised trial (Postmenopausal Estrogen/Progestin Interventions Trial, PEPI) it was shown to improve lipoprotein profile and decrease plasma fibrinogen (154). In the same study a decrease of soluble E-selectin was seen (155). which was in line with the decrease of another soluble marker of inflammation, ICAM, in another study (156). However, results from the PEPI trial also showed an increase in Creactive protein. which renders the effects of hormone substitution on inflammation difficult to interpret (155). Effects on coagulation are similar to those of oral contraceptives, with evidence for coagulation activation, increased APC-resistance. increased factor VII, decreased antithrombin, and increased fibrinolytic activity by a decrease in PAI-1 (157) (reviewed in [158]), although the effects are not consistent among studies (159). The effects on inflammation markers, as well as on several coagulation parameters (factor IX, APC-ratio, PAI-1, t-PA) were only seen with oral hormone replacement therapy and not with transdermal patches $(156,160)$

\section{Conclusion}

Oral contraceptives increase the risk of venous thrombosis at all oestrogen dosage formulations. This risk does not seem to have been lowered much, if at all, by dose reductions below $50 \mu \mathrm{g}$ ethinyloestradiol, and is also influenced by the type of progestogen, i.e., so-called third generation progestogens (desogestrel and gestodene) increase the risk further. Oral contraceptives also increase the risk of myocardial infarction and stroke. In absolute terms, except for first-time users in the first year of use, these increases in risk are small. Therefore, the probability of complications need not outweigh the benefits of oral contraceptives, or compare unfavourably to the complication rates of other methods of birth control. Obviously, once an oral contraception is prescribed, the safest one should be used, especially since all monophasic combined oral contraceptives have equal efficacy and minor side-effect frequencies. Therefore, there is no place for third generation contraceptives, unless other contraceptives are poorly tolerated and provided the woman is informed about the increased thrombotic risks.

Even though there is little doubt that the risk of thrombosis is greatly enhanced in the concomittant presence of prothrombotic abnormalities, such as the frequently occurring factor $\mathrm{V}$ Leiden and prothrombin 20210A, no case can yet be made in favour of indiscriminate screening for these abnormalities prior to prescription. While obtaining information on a family history of venous thrombosis seems useful, it is atso unclear whether a positive family history should lead to screening with selective withholding of oral contraceptives, or other policies (such as withholding oral contraceptives in all women with a positive family history). A personal history of thrombosis is a contra-indication for oral contraceptive use.

Hormone replacement therapy has been shown to ameliorate symptoms of menopause, and to reduce the progression of osteoporo sis, but has not produced the expected reduction in cardiovascular disease. It increases the risk of venous thrombosis, and has, in the only randomised trial so far of women with prior coronary disease, not 
that in werall benefit. It is yet to be determined if subgroups of isserpinle woment can be identified, so that in future the therapy can whtheld from women whom it might harm, and be prescribed to \&. a $\mathrm{a}$ is hum th would benefit.

ingers

W. Wrum .1. Lindblad B, Bergqvist D. Kjellström T. A prospective : wh the incidence of deep-vein thrombosis within a defined urban * uluturn. J Intern Med 1992; 232: 155-60.

Arrum F.. Wheeler HB. Goldberg RJ, Hosmer DW. Patwardhan NA.

I n n

3. nitul inidence and case-fatality rates of deep vein thrombosis and pul-

.... embolism. The Worcester DVT study. Arch Intern Med 1991:

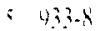

: ( wre C. The natural history and epidemiology of venous thrombosis. Pr ve Curdurasc Dis 1994; 36: 423-38.

: He: I A. Silvertein MD, Mohr DN. Petterson TM. O'Fallon WM, Melton

U) III Predictors of survival after deep vein thrombosis and pulmonary

$\therefore$ nlivm: a population-based. cohort study. Arch Intern Med 1999: 159: +5:

‘ Sminneal G. Sors H. Charbonnier B, Page Y. Laaban JP, Azarian R. Lusern .M. Hirsch JL. Ferrari E. Bosson JL, Mottier D. Beau B. A compain: of low-molecular-weight heparin with unfractionated heparin for sute pulmonary embolism. The THESEE Study Group. Tinzaparine ou Horurine Standard: Evaluations dans l'Embolie Pulmonaire. N Engl J Med :34, 337: 663-9.

- Curvun JL. Kelley MA, Duff A, Weg JG. Fulkerson WJ, Palevsky HI. S.thu arz JS. Thompson BT, Popovich J. Jr., Hobbins TE. The clinical Ailfere of pulmonary embolism. N Engl J Med 1992: 326: 1240-5.

- The Columbus Investigators. Low-molecular-weight heparin in the treatment of patients with venous thromboembolism. N Engl J Med 1997; 337 4:"-62.

: Brundję DP. Büller HR. Heijboer H, Huisman MV. de Rijk M, Jagt H, Ten Cule JW: Randomised trial of effect of compression stockings in paitne with symptomatic proximal-vein thrombosis. Lancet 1997: 349 $-34-6)$.

- Ir.hou R. Phlogose und Thrombose in Gefäßsystem: Gesammelte Abr.undlungen zur Wissenschaftlichen Medizin. Frankfurt. Staatsdruckere $\therefore .56$

- Jirdan WM. Pulmonary embolism. Lancet 1961: i: 1146-7.

D.ty E. V'essey MP. Hawkins MM, Carson JL. Gough P, Marsh S. Risk of senou ihromboembolism in users of hormone replacement therapy. Lan(2) 1996: 348: 977-80

: Jk H. Derby LE. Wald Myers M. Vasilakis C. Newton KM. Risk of hosfital admission for idiopathic venous thromboembolism among users of Mutmenopasusal oestrogens. Lancet 1996: 348: 981-3.

$\therefore$ Grodstein F. Stampfer MJ, Goldhaber SZ, Manson JE. Colditz GA, Speizet FE. Willett WC, Hennekens CH. Prospective study of exogenous hormones and risk of pulmonary embolism in women. Lancet 1996; 348 $9 \times 3.7$

it The Coronary Drug Project Research Group. The Coronary Drug Project. Findings leading to discontinuation of the $2.5-\mathrm{mg}$ day estrogen group. H.1.A 1973: 226: 652-7.

' an Kesteren PJ. Asscheman H. Megens JA. Gooren LJ. Mortality and murhidity in transsexual subjects treated with cross-sex hormones. Clin Enúlicinol (Oxf) 1997: 47: 337-42.

"Biremenkamp KWM, Rosendaal FR, Helmerhorst FM. Büller HR, VanJenhroucke JP. Enhancement by factor V Leiden mutation of risk of deepWin thrombosis associated with oral contraceptives containing a thirdseivituon progestagen. Lancet 1995: 346: 1593-6.

H.rly Health Organization. Effect of different progestagens in low Wirten oral contraceptives on venous thromboembolic disease. World
Health Organization Collaborative Study of Cardiovascular Disease and Steroid Hormone Contraception. Lancet 1995: 346: 1582-8.

18. Jick H. Jick SS. Gurewich V. Myers MW. Vasilakis C. Risk of idiopathic cardio ascular death and nonfatal venous thromboembolism in women using oral contraceptives with differing progestagen components. Lancet 1995: 346: 1589-93.

19. Vasilakis C. Jick H. Mar Melero-Montes M. Risk of idiopathic venous thromboembolism in users of progestagens alone. Lancet 1999:354: 1610-1.

20. Lewis MA. Heinemann LA. MacRae KD. Bruppacher R. Spitzer WO. The increased risk of venous thromboembolism and the use of third generation progestagens: role of bias in observational research. The Transnational Research Group on Oral Contraceptives and the Health of Young Women. Contraception 1996: 54: 5-13.

21. Fu H. Darroch JE. Haas T. Ranjit N. Contraceptive failure rates: new estimates from the 1995 National Survey of Family Growth. Fam Plann Perspect 1999: 31: 56-63.

22. Haberlandt L. Über hormonale Sterilisierung des weiblichen Tierkörpers. Munich Med Wschr 1921: 68: 1577-8.

23. United Nations Department for Economic and Social Information and Policy Analysis Population Division. Levels and trends of contraceptive use as assessed in 1994. United Nations. New York. 1996.

24. Records Unit and Research Advisory Service of the Royal College of General Practioners. Oral contraception and thrombo-embolic disease. J R Coil Gen Pract 1967: 13: 267-79

25. Vessey MP. Doil R. Investigation of relation between use of oral contraceptives and thromboembolic disease. Br Med J 1968: 2: 199-205.

26. Vessey MP. Doll R. Investigation of relation between use of oral contraceptives and thromboembolic disease: a further report. Br Med J 1969: 2: 651-7.

27. Sartwell PE. Masi AT. Arthes FG. Greene GR. Smith HE. Thromboembolism and oral contraceptives: an epidemiological case-control study. Am J Epidemiol 1969: 90: 365-80.

28. Boston Collaborative Drug Surveillance Program. Oral contraceptives and venous thromboembolic disease, surgically confirmed gall bladder disease and breast tumours. Lancet 1973; i: 1399-404

29. Porter JB. Oral contraceptives and nonfatal vascular disease - recent experience. Obstet Gynecol 1982: 59: 299-302.

30. Royal College of General Practioners" Oral Contraception Study. Oral contraceptives. venous thrombosis, and varicose veins. J R Coll Gen Pract 1978: 28: 393-9.

31. Vessey M, Mant D. Smith A. Yeates D. Oral contraceptives and venous thromboembolism: findings in a large prospective study. Br Med 1 1986; 292: 526 .

32. Koster T. Small RA. Rosendaal FR. Helmerhorst FM. Oral contraceptives and venous thromboembolism: a quantitative discussion of the uncertainties. J Intern Med 1995: 238: 31-7.

33. Inman WHW. Vessey MP. Investigation of death from pulmonary. coronary. and cerebral thrombosis and embolism in women of child-bearing age. Br Med J 1968: 2: 193-9.

34. Lensing AW, Prandoni P, Brandjes D, Huisman PM. Vigo M, Tomasella G, Krekt J, Wouter TC. Huisman MV, Buller HR. Detection of deep-vein thrombosis by real-time B-mode ultrasonography. N Engl J Med 1989: 320: $342-5$.

35. Huisman MV. Buller HR, Ten Cate JW, Vreeken J. Serial impedance plethysmography for suspected deep venous thrombosis in outpatients. The Amsterdam General Practitioner Siudy. N Engl J Med 1986; 314: 823-8.

36. Stolley PD. Tonascia JA. Tockman MS. Sartwell PE, Rutledge AH. Jacobs MP. Thrombosis with low-estrogen oral contraceptives. Am J Epidemiol 1975: 102: 197-208.

37. Vandenbroucke JP. Koster T. Briët E. Reitsma PH. Bertina RM. Rosendaal FR. Increased risk of venous thrombosis in oral-contraceptive user who are carriers of factor $V$ Leiden mutation. Lancet 1994: 344: 1453-7.

38. Thorogood M. Mann J. Murphy M. Vessey M. Risk factors for fatal venous thromboembolism in young women: a case-control study. Int J Epidemiol 1992: 21: 48-52 
39. World Health Organization. Venous thrombuembolic disease and combined oral contraceptives: results of international multicentre case-control study. World Health Organization Collaborative Study of Cardionascular Disease and Steroid Hormone Contraception. Lancet 1995: 346: 1575-82.

40. Farmer RDT. Preston TD. The risk of venous thromboembolism associated with low-oestrogen oral contraceptivcs. J Obst Gynecol 1995: 15: 195-200.

41. Silverstein MD. Heit JA. Mohr DN. Petterson TM. O'Fallon WM, Melton LJ. Trends in the incidence of deep vein thrombosis and pulmonary embolism: a 25-year population-based study. Arch Intern Med 1998: 158: $585-93$.

42. Rosendaal FR. Thrombosis in the young: epidemiology and risk factors. a focus on venous thrombosis. Thromb Haemost 1997: 78: 1-6.

43. Jick H, Kaye JA. Vasilakis-Scaramozza C. Jick SS. Risk of venous thromboembolism among users of third generation oral contraceptives compared with users of oral contraceptives with levonorgestrel before and after 1995: cohort and case-control analysis. Br Med J 2000; 321: 1 190-5.

44. Rosendaal FR. Risk factors for venous thrombotic disease. Thromb Haemost 1999; 82: 610-9

45. Realini JP. Encarnacion CE, Chintapalli KN. Rees CR. Oral contraceptives and venous thromboembolism: a case-control study designed to minimize detection bias. J Am Board Fam Pract 1997: 10: 315-21.

46. Bloemenkamp KWM. Rosendaal FR, Helmerhorst FM, Büller HR. Colly LP, Vandenbroucke JP. The association between oral contraceptives and venous thrombosis: the myth of the diagnostic suspicion- and referral bias. Arch Intern Med 1999: 159:65-70.

47. Gerstman BB. Piper JM. Tomita DK. Ferguson WJ. Stadel BV. Lundin FE. Oral contraceptive estrogen dose and the risk of deep venous thromboembolic disease. Am J Epidemiol 1991; 133: $32-7$.

48. Helmrich SP. Rosenberg L. Kaufman DW. Strom B. Shapiro S. Venous thromboembolism in relation to oral contraceptive use. Obstet Gynecol 1987:69:91-5.

49. Spitzer WO. Lewis MA. Heinemann LA. Thorogood M. MacRae KD. Third generation oral contraceptives and risk of venous thromboembolic disorders: an international case-control study. Transnational Research group on Oral Contraceptives and the Health of Young Women. Br Med J 1996: 312: 83-8.

50. Bennet L. Odeberg H. Resistance to activated protein C, highly prevalent amongst users of oral contraceptives with venous thromboembolism. J Intern Med 1998; 244: 27-32.

51. Andersen BS. Olsen J, Nielsen GL. Steffensen FH. Sørensen HT. Baech J. Gregersen $\mathrm{H}$. Third generation oral contraceptives and heritable thrombophilia as risk factors for non-fatal venous thromboembolism. Thromb Haemost 1998: 79: 28-31

52. Vasilakis C. Jick SS. Jick H. The risk of venous thromboembolism in users of postcoital contraceptive pills. Contraception 1999: 59: 79-83.

53. Herings RMC. Urquhart J. Leufkens HGM. Venous thromboembolism among new users of different oral contraceptives. Lancet 1999: 354: $127-8$

54. Martinelli I. Taioli E, Bucciarelli P. Akhavan S, Mannucci PM. Interaction between the G20210A mutation of the prothrombin gene and oral contraceptive use in deep vein thrombosis. Arterioscler Thromb Vase Biol 1999 19: 700-3

55. Lidegaard $\emptyset$, Edstrom B. Kreiner S. Oral contraceptives and venous thromboembolism. A case-control study. Contraception 1998: 57: 291-301.

56. Farmer RD, Lawrenson RA. Thompson CR. Kennedy JG. Hambleton IR Population-based study of risk of venous thromboembolism associated with various oral contraceptives. Lancet 1997: 349: 83-8.

57. Farmer RD. Todd JC. MacRae KD. Williams TJ, Lewis MA. Oral contraception was not associated with venous thromboembolic disease in recent study. Br Med J 1998: 316: 1090-1.

58. Vandenbroucke JP. Medical journals and the shaping of knowledge. Lancet 1998: 352: 2001-6.

59. Vandenbroucke JP. Helmerhorst FM. Rosendaal FR. BMJ readers should know whose words they read. Br Med J 2000; 320: $381-2$.
60. V'andenbrouke JP. Bloemenkamp KWM. Rouendaal FR. Helnerhorst F.Y Incidence of icnous thromboembolism in users of combined oral contraceptives. Rish is particularly high uith tirst use of oral contraceptives BMJ 2000: 320:57-8.

61. Spitzer WO. Thromboembolism and the pill: the saga must end. Human Reproduction 1998: 13: 1117-8.

62. Helmerhorst FM, Rosendaal FR. Vandenbroucke JP. The pill and venous thromboembolism: a disarray of several layers of debate. Human Reproduction 1998: 13: 1119-20.

63. Spitzer WO. Balanced view of risks of oral contraceptive. Lancet 1997 350: 1566-7.

64. Meirik O. Risks of oral contraceptives. Lancet 1998: 351: 521.

65. Lidegaard $\varnothing$. Oral contraceptives and venous thromboembolism: an epidemiological review. Eur J Contracept Reprod Health Care 1996; 1: 13-20.

66. Cramer DW. Safety of combined oral contraceptive pills. Lancet 1996 347: 546-8.

67. Suissa S. Blais L. Spizzer WO. Cusson J. Lewis M. Heinemann L. Firsttime use of newer oral contraceptives and the risk of venous thromboembolism. Contraception 1997; 56: 141-6.

68. Farmer RD. Williams TJ, Simpson EL. Nightingale AL. Effect of 1995 pill scare on rates of venous thromboembolism among women taking com bined oral contraceptives: analysis of general practice research database. Br Med J 2000: 321: 477-9.

69. Todd J, Lawrenson R, Farmer RD. Williams TJ. Leydon GM. Venou thromboembolic disease and combined oral contraceptives: A re-analysi of the MediPlus database. Hum Reprod 1999; 14: 1500-5.

70. Weiss NS. Bias in studies of venous thromboembolism in relation to the use of new formulations of oral contraceptives. Contraception 1997: 55 189.90.

71. Vandenbroucke JP, Bloemenkamp KWM. Heimerhorst FM. Rosendaal FR. Risk of oral contraceptives and recency of market introduction. Contraception 1997: 55: 191-2.

72. Farley TM. Meirik O, Marmot MG. Chang CL. Poulter NR. Oral contraceptives and risk of venous thromboembolism: impact of duration of use. Contraception 1998: 57: 61-5.

73. Skegg DCG. Pitfalls of pharmacoepidemiology. Br Med J 2000; 321: $1171-2$

74. Skegg DCG. Third generation contraceptives: caution is still justified BMJ 2000: 321: 190-1.

75. O'Brien PA. The third generation oral contraceptive controversy: The erdence shows they are less safe than second generation pills. Br Med 1999: 319: 795-6.

76. Hannaford P. Science is not a dispassionate aciivity. Br Med J 2000:37 382.

77. Vandenbroucke JP. Helmerhorst FM. Bloemenkamp KWM. Rosenda: FR. Third-generation oral contraceptive and deep venous thrombow from epidemiologic controversy to new insight in coagulation. Am . Obstet Gynecol 1997: 177: 887-91

78. Walker AM. Newer oral contraceptives and the risk of venous inrom boembolism. Contraception 1998; 57: 169-81.

79. Farley TMM, Meirik O, Collins J. Cardiovascular disease and conthnat oral contraceptives: reviewing the evidence and balancing the risk. Hurt Reprod Update 1999: 5: 721-35.

80. World Health Organization. Cardiovascular disease and steroic hormure contraception. Report of a WHO Scientific group. WHO Technical Rępr: Series, no. 877. World Health Organization, 1998. Geneva.

81. Lewis MA, Heinemann LA. Spitzer WO. MacRae KD, Bruppacher R Th use of oral contraceptives and the occurrence of acute myocardial ints: tion in young women. Results from the Transnational Study on Oral $\mathrm{Cr}$ traceptives and the Health of Young Women. Contraception 199?: * 129-40.

82. Jick H, Jick S. Myers MW, Vasilakis C. Risk of acute myocurdtal inist. tion and low-dose combined oral contraceptives. Lancet 1996: 347: 6.t.

83. World Health Organization. Acute myocardial infarction and conthist oral contraceptives: results of an international multicentre case-onst 
WHO Collaborative Study of Cardiovascular Disease and Steroid thanthi Contraception. Lancet 1997: 349: 1202-9.

4: Dann X. Thurogood M. Faragher B, de Caestecker L, MacDonald TM. V. C. Hum C. Thumas S. Mann R. Oral contraceptives and myocardial in-

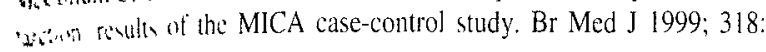

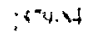

- Bhmer f Cigulation effects of oral contraception. Am J Obstet Gynecol is $15^{\circ}$ " $1042-8$.

* surnluticld PG. Cardiovascular effects of oral contraceptives: a review. In I Frnt 1989: 34 (Suppl): 40-9.

* R.ming J. Tan G, Nicolaes GA, Thomassen MC, Van Oerle R, Van der Pixy PVI. Hejien P. Hamulyak K, Hemker HC. Oral contraceptives and - in in inrumbosis: different sensitivities to activated protein $\mathrm{C}$ in women wron liund and third-generation oral contraceptives. Br J Haematol (w) $y^{2} .233-8$.

" Danthak B. Carlsson M. Svensson PJ. Familial thrombophilia due to a friwul! unrecognised mechanism characterized by poor anticoagulant

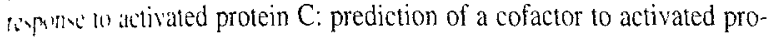
cun C Pric Watl Acad Sci USA 1993: 90: 1004-8.

" $J:$ Rimd: H. Bertina RM. Laboratory diagnosis of APC-resistance: a critial suatwon of the test and the development of diagnostic criteria. Thromb Hatemos 1994: 72: 880-6.

* He:ker. C.M. Bom VJ. Seinen AJ, van der Meer J. Sensitivity to activated proven $C$ influence of oral contraceptives and sex. Thromb Haemost (44) $73: 402-4$

If Ohukri O. Friso S. Manzato F, Guella A. Bernardi F, Lunghi B. Girelli D. A//In M. Brocco G. Russo C. Resistance to activated protein C in healthy Wumin taking oral contraceptives. Br J Haematol 1995: 91: 465-70.

4: Romng J. Middeldorp S, Curvers J, Christella M, Thomassen LG, Nicolaes GA. Meijers JC, Bouma BN, Buller HR, Prins MH, Tans G. Low-dose oral contraceptives and acquired resistance to activated protein $\mathrm{C}$ : a randomued cross-over study. Lancet 1999: 354: 2036-40.

43. Whddeldorp S. Meijers JCM, van den Ende AE, van Enk A, Bouma BN, Tan G. Rosing J, Prins MH, Büller HR. Effects on coagulation of kuunorgestrel- and desogestrel-containing low dose oral contraceptives: a cross-over study. Thromb Haemost 2000; 84: 4-8.

4 Meijers JCM. Middeldorp S, Tekelenburg W, van den Ende AE. Tans G. Prin MH. Rosing J, Büller HR, Bouma BN. Increased fibrinolytic activity Juring use of oral contraceptives is counteracted by an enhanced factor XIindependent down regulation of fibrinolysis: a randomized cross-over tudy of two low-dose oral contraceptives. Thromb Haemost 2000: 84: 9-14.

45. Tan. G. Curvers J, Middeldorp S, Thomassen MCLGD. Meijers JCM. Prini MH. Bouma BN, Builler HR, Rosing I. A randomized cross-over sudy on the effects of levonorgestrel- and desogestrel-containing oral conraceptives on the anticoagulant pathways. Thromb Haemost 2000: 84: 15-21.

*. Kluft C. Lansink M. Effect of oral contraceptives on haemostasis variatles. Thromb Haemost 1997; 78: 315-26.

9?. Bellert FK. Ebert C. Effects of oral contraceptives on blood coagulation: a review, Obstet Gynecol Surv 1985: 40: 425-36.

98. Tans G. Rosendaal FR, Curvers J. Thomassen MCLGD, Bertina RM. Rosing J. APC-resistance determined with the endogenous thrombin generation potential is associated with venous thrombosis: a blinded clinical evaluation.Thromb Haemost 1999: 82: S202-3a (abstr).

99. Pabinger I. Schneider B, and the GTH study group. Thrombotic risk of women with hereditary antithrombin III-, protein $C$ and protein S-deficiency laking oral contraceptive medication. Thromb Haemost 1994: 71: 5+8-52.

100. Simioni P, Sanson BJ. Prandoni P. Tormene D. Friederich PW. Girolami B. Gavasso S, Huisman MV. Buller HR. Wouter TC. Girolami A, Prins $\mathrm{MH}$. Incidence of venous thromboembolism in families with inherited thrombophilia. Thromb Haemost 1999: 81: 198-202

[01. Hellgren M. Svensson PJ. Dahlbäck B. Resistance to activated protein C as a basis for venous thromboembolism associated with pregnancy and oral contraceptives. Am J Obstet Gynecol 1995: 173: 210-5.
102. Hirsch DR, Mikkola KM. Marks PW. Fox EA. Dorfman DM. Ewenstein BM. Goldhaber SZ. Pulmonary embolism and deep venous thronbosis during pregnancy or oral contraceptive use: prevalence of factor $\mathrm{V}$ Leiden. Am Heart J 1996: 131: 1145-8.

103. Rosendaal FR. Koster T. Vandenhroucke JP. Reitsma PH. High rish of thrombosis in patients homozygous for factor V Leiden (activated protein C resistance). Blood 1995: 85: 1504-8.

104. Rintelen C. Mannhalter C, Ireland H, Lane DA. Knobl P, Lechner K. Pabinger I. Oral contraceptives cnhance the risk of clinical manifestation of venous thrombosis at a young age in females homozygous for factor $\mathrm{V}$ Leiden. Br J Haematol 1996: 93: 487-90.

105. Poort SR. Rosendaal FR. Reitsma PH. Bertina RM. A common genetic variation in the 3 -untranslated region of the prothrombin gene is associated with elcvated plasma prothrombin levels and an increase in venous thrombosis. Blood 1996: 88: 3698-703.

106. Kamphuisen PW. Eikenboom JCJ, Vos HL, Pablo R. Sturk A. Bertina RM, Rosendaal FR. Increased levels of factor VIIl and fibrinogen in patients with venous thrombosis are not causcd by acute phase reactions. Thromb Haemost 1999: 81: 680-3.

107. Koster T, Blann AD, Briëı E. Vandenbroucke JP. Rosendaal FR. Role of clotting factor VIII in effect of von Willebrand factor on occurrence of deep-vein thrombosis. Lancet 1995: 345: 152-5.

108. Bloemenkamp KWM, Helmerhorst FM, Rosendaal FR. Vandenbroucke JP. Venous thrombosis, oral contraceptives and high factor VIII levels. Thromb Haemost 1999: 82: 1024-7.

109. de Bruijn SF. Stam J. Koopman MM. Vandenbroucke JP. Case-control study of risk of cercbral sinus thrombosis in oral contraceptive users who are carriers of hereditary prothrombotic conditions. Br Med J 1998; 316: $589-92$.

110. Martinelli I. Sacchi E, Landi G. Taioli E. Duca F. Mannucci PM. High risk of cerebral-vein thrombosis in carriers of the prothrombin-gene mutation and in users of oral contraceptives. N Engl J Med 1998; 338: 1793-7.

111. Rosendaal FR. Risk factors for venous thrombosis: prevalence. risk and interaction. Semin Hematol 1997; 34: 171-87.

112. Rosendaal FR. Oral contraceptives and screening for factor V Leiden Thromb Hacmost 1996: 75: 524-5.

113. Vandenbroucke JP, van der Meer FJM, Helmerhorsl FM. Rosendaal FR Factor V Leiden: should we screen oral contraceptive users and pregnant women? Br Med J 1996: 313: 1127-30.

114. Schambeck CM. Schwender S. Haubitz I. Geisen UE. Grossmann RE, Keller F. Selective screening for the Factor V Leiden mutation: is it advisable prior to the prescription of oral contraceptives? Thromb Haemost 1997: $78:$ : $1480-3$

115. Scarabin PY. Plu-Bureau G, Zitoun D. Bara L, Guize L. Samama MM Changes in haemostatic variables induced by oral contraceptives containing 50 micrograms or 30 micrograms oestrogen: absence of dose-dependent effect on PAI- 1 activity. Thromb Haemost 1995; 74: 928-32.

116. Quehenberger P. Loner U, Kapiotis S. Handler S. Schneider B. Huber J, Speiser W. Increased levels of activated factor VII and decreased plasma protein $S$ activity and circulating thrombomodulin during use of oral contraceptives. Thromb Haemost 1996: 76: 729-34.

117. World Heath Organization TFoOC. A multicentre study of coagulation and haemostatic variables during oral contraception: variations with four formulations. Br J Obstet Gynaecol 1991: 98: 1117-28.

118. Meade TW. Haines AP. North WR, Chakrabarti R, Howarth DJ. Stirling $Y$. Haemostatic. lipid. and blood-pressure profiles of women on oral contraceptives containing 50 microgram or 30 microgram oestrogen. Lancet 1977: 2: 948-51.

119. Rosendaal FR. Venous thrombosis: a multicausal disease. Lancet 1999: 353: 1167-73.

120. Bloemenkamp KWM. Rosendaal FR. Helmerhorsi FM. Koster T. Berlina RM. Vandenbroucke JP. Hemostatic elfects of oral contraceptives in women who developed deep-vein thrombosis while using oral contraceptives. Thromb Haemos 1998: 80: 382-7. 
121. Boyce J. Faucet JW. Noall EWP. Coronaly thromboss and Conoud. Lancet 1963: 1: 111.

122. Collaborative Group tor the Study of Stroke in Young Women. Oral contraception and increased risk of cerebral ischemia or thrombosis. N Engl J Med 1973: 288: 871-8.

123. World Health Organization. Ischaemic stroke and combined oral contraceptives: results of an international, multicentre, case-control study. WHO Collaborative Study of Cardiov ascular Disease and Steroid Hormone Contraception. Lancet 1996: 348: 498-505.

124. World Health Organization. Haemorrhagic stroke overall stroke risk. and combined oral contraceptives: results of an internatonal. multicentre. case-control study. WHO Collaboratıve Study of Cardiovascular Disease and Steroid Hormone Contraception. Lancet 1996: 348. 505-10.

125. Boston Collaboratuve Drug Sur eillance program. Surgically confirmed gallbladder disease. venous thromboembolism and breast tumors in relation to postmenopausal estrogen therapy. N Engl J Med 1974: 290: 15-9.

126. Grady D, Rubin SM. Petitti DB. Fox CS. Black D. Ettinger B, Ernster VL, Cummings SR. Hormone therapy to prevent disease and prolong life in postmenopausal women. Ann Intern Med 1992; 117: 1016-37.

127. Hutchınson TA, Polansky SM. Feinstein AR. Post-menopausal oestrogens protect against fractures of hip and distal radius. A case-control study. Lancet 1979:2: 705-9.

128. Weiss NS, Ure CL. Ballard JH. Williams AR, Daling JR. Decreased risk of fractures of the hip and lower forearm with postmenopausal use of estrogen. N Engl J Med 1980; 303: 1195-8.

129. Stampfer MJ. Willett WC. Colditz GA. Rosner B. Speizer FE. Hennekens $\mathrm{CH}$. A prospective study of postmenopausal estrogen therapy and coronary heart disease. N Engl J Med 1985: 313: 1044-9.

130. Psaty BM. Heckbert SR. Atkıns D. Siscor ick DS. Koepsell TD, Wahl PW. Longstreth WT, Jr., Weiss NS. Wagner EH, Prentice R. A revew of the association of estrogens and progestins with cardiovascular disease in postmenopausal women. Arch Intern Med 1993; 153: 1421-7.

131. Bush TL. Cowan LD, Barrett-Connor E, Criqu MH. Karon JM, Wallace RB, Tyroler HA. Rufkind BM. Estrogen use and all-cause mortality. Preliminary results from the Lipid Research Clinics Program Follow-Up Study. JAMA 1983: 249: 903-6.

132. Ross RK. Paganini-Hill A. Mack TM. Arthur M. Henderson BE. Menopausal oestrogen therapy and protection from death from ischaemic heart disease. Lancet 1981: 1: 858-60.

133. Nachtigall LE. Nachtigall RH. Nachtigall RD, Beckman EM. Estrogen replacement therapy I: a 10-year prospective study in the relationship to osteoporosis. Obstet Gynecol 1979: 53: $277-81$.

134. Hemminkı E. Sihvo S. A rev iew of postmenopausal hormone therapy recommendations: potential for selection bias. Obstet Gynecol 1993; 82: $1021-8$.

135. Hemmınki E. Malin M. Topo P. Selection to postmenopausal therapy by women's characteristics. J Clin Epidemiol 1993: +6: 211-9.

136. Posthuma WF. Westendorp RG. Vandenbroucke JP. Cardıoprotective effect of hormone replacement therapy in postmenopausal women is the evidence biased" Br Med J 1994: 308: 1268-9.

137. Høibraaten E. Qvigstad E. Arnesen H. Larsen S. Wackstrøm E. Sandset PM. Increased nsk of recurrent venous thromboembolism during hormone replacement therapy - results of the randomized. double-blind. placebocontrolled estrogen in venous thromboembolism trial (EVTET). Thromb Haemost 2000: 84: 961-7.

138. Nachtigall LE. Nachtigall RH. Nachtigall RD, Beckman EM. Estrogen replacement therapy II: a prospective study in the relationship to carcinoma and cardrovascular and metabolic problems. Obstet Gynecol 1979: 54: 74-9.

139. Devor M. Barrett-Connor E. Renvall M. Fergal D. Jr.. Ramsdell J. Estrogen replacement therapy and the risk of venous thrombosis. Am J Med 1992: 92: 275-82.

140. Pettti DB. Wingerd J. Pellegrin F. Rancharan S. Risk of vascular disease in women. Smoking, oral contraceptives. noncontraceptive estrogens. and other factors. JAMA. 1979: 242: 1150-4.
1+1 Young RL. Gocptert AR. Goldzicher HW. Estrogen replacement therapy is not conduche of venous thromboembols m Maturitas 1991. 13 189-92.

142. Daly E. Vesey MP. Panter R. Haukins MM. Case-control study of ienous thromboembolssm risk in users of hormone replacement therapy. Lancet 1996: 3+8. 1027

1+3. Varas Lorenzo C. Garcia Rodriguez LA. Cattaruzzı C. Troncon MG. Agostuns L. Perez Guthann S. Hormone replacement therapy and the risk of hospitalization for venous thromboembolism: a population-based study in southern Europe. Am J Epidemiol 1998: 147: 387-90.

1+4. Perez Gutthann S. Garcia Rodriguez LA. Castellsague J, Duque Oliart A. Hormone replacement therapy and risk of venous thromboembolism. population based case-control study. Br Med J 1997: 314: 796-800.

145. Grady D. Furberg C. Venous thromboembolic events associated with hormone replacement therapy. JAMA 1997; 278: 477.

146. Grady D. Wenger NK. Hernngton D, Khan S. Furberg C. Hunninghoke D. Vitinghoff E. Hulley S. Postmenopausal hormone therapy increases risk for venous thromboembolic disease. Ann Intern Med 2000; 132: $689-96$.

147. Høibraaten E. Abdelnoor M. Sandset PM. Hormone replacement therapy with estradiol and risk of venous thromboembolism - a population-based case-control study. Thromb Haemost 1999; 82: 1218-21.

148. Hulley S. Grady D. Bush T. Furberg C. Herrington D. Riggs B, Vittinghoff E. for the Heart and estrogen/progestin Replacement Study (HERS) Research Group. Randomized trial of estrogen plus progestin for secondary prevention of coronary heart disease in postmenopausal women. JAMA 1998: 280: 605-13.

149. The Women's Health Initiative Investigators. Design of the Women's Health Intiative Clinical Trial and Observational Study. Controlled Clin Trials 1998: 19:61-109.

150. Larkin M. Ups and downs for HRT and heart disease. Lancet 2000; 355: 1338.

151. Bloemenkamp KWM. Rosendaal FR. Helmerhorst FM, Vandenbroucke JP. Higher risk of venous thrombosis durng early use of oral contraceptives in women with inherited clotting defects. Arch Intern Med 2000; 160: 49-52.

152. Lowe G, Woodward M. Vessey M, Rumley A, Gough P, Daly E. Thrombotic variables and risk of idiopathic venous thromboembolism in women aged 45-64 years: relationships to hormone replacement therapy. Thromb Haemost 2000: 83: 530-5.

153. Psaty BM, Smith NL. Lemaitre RN, Vos HL, Heckbert SR, Lacroix AZ, Rosendaal FR. Hormone replacement therapy, prothrombotic mutations, and the risk of incident non-fatal myocardial infarction. JAMA 2001: 285: 906-13.

154. The Writing Group for the PEPI Trial. Effects of estrogen or estrogen/ progestn regimens on heart disease risk factors in postmenopausal women. The Postmenopausal Estrogen/Progestin Interventions (PEPI Trial. JAMA 1995; 273: 199-208.

155. Cushman M. Legault C. Barrett-Connor E. Stefanick ML. Kessler C. Judd HL, Sakkinen PA. Tracy RP. Effect of postmenopausal hormones on inflammation-sensitive proteins: the Postmenopausal Estrogen/Progestin Interventions (PEPI) Study. Circulation 1999; 100: 717-22.

156. Scarabin PY, Alhenc-Gelas M, Oger E. Plu-Bureau G. Hormone replacement therapy and crrculating ICAM-1 in postmenopausal women a randomised controlled trial. Thromb Haemost 1999: 81: 673-5.

157. Teede HJ, McGrath BP. Smolich JJ. Malan E, Kotsopoulos D, Liang YL. Peverill RE. Postmenopausal hormone replacement therapy increases coagulation activity and fibrinolysis. Arterioscler Thromb Vasc Biol 2000. 20: $1404-9$

158. Koh KK. Horne MK. III. Cannon RO, III. Effects of hormone replacement therapy on coagulation. fibrinolysis, and thrombosis risk in postmenopau. sal women. Thromb Haenost 1999: 82: 626-33.

159 Douketis JD. Gordon M. Johnston M, Julian JA. Adachi JR, Ginsberg JS. The effects of hormone replacement therapy on thrombin generation. fibrinolysis inhibition. and resistance to activated proten C: prospecture cohort study and review of literature. Thromb Res 2000; 99: 25-34. 
x. CGDO. Lpton MN. Rumley A, McConnachie A, O'Reilly DSJ, Watt ay Diftrent effects of oral and transdermal hormone replacement 20 an factor IX, APC resistance, TPA, PAI and C-reactive a inin

* Lsmiut DJ. A retrospective case-control study of diseases associated - in wiontracepture use. Am Heart J 1975; 89: 677-8.

a Fi in DB. Wingerd J. Pellegrin F, Ramcharan S. Oral contraceptives, Fir. and other factors in relation to risk of venous thromboembolic A. viss Am J Epidemiol 1978; 108: 480-5.

a Vire MG. Tonascia JA, Sartwell PE, Stolley PD, Tockman MS isicusd rish of thrombosis due to oral contraceptives: a further report. fim I E.pudemol 1979; 110: 188-95.
164. World Health Organization. Cardios ascular disease and use of oral contraceptives. WHO Bulletn OMS 1989; 67: 417-23.

165. Grounds M. Anovulants: thrombosis and other associated changes. Med J Aust 1974: 2: 440-6

166. Diddle AW, Gardner WMH. Willamson PH. Johnson JR. Hemphill JL. Godwin CW. Oral contraceptives sterolds and thrombophlebitis. J Tenn Med Assoc 1978: 71: 22-6.

167. Porter JB, Hunter JR. Jick H. Stergachis A. Oral contraceptsves and nonfatal vascular diseasc. Obstet Gynecol 1985; 66: 1-4.

168. Fuertes de la Haba A. Curet JO. Pelegrina I. Bangdiwala I. Thrombophlebitis among oral and nonoral contraceptive users. Obstet Gynecol 1971: 38: 259-63.

169. Walker AM. Martın-Moreno JM. Artalejo FR. Odd man out: a graphıcal approach to meta-analysis. Am J Public Health 1988; 78. 961-6. 